\title{
ANALISIS NILAI MORAL PEMBIASAAN PENGUCAPAN TERIMA KASIH PADA ANAK USIA 4-5 TAHUN DI KECAMATAN PONTIANAK KOTA
}

\section{Halida $^{1}$ dan Tri Wirawati ${ }^{2}$}

\begin{abstract}
Abstrak : Penanaman nilai agama, moral, disiplin dan afeksi yang dalam program pendidikan Taman Kanak-kanak yang disingkat dengan TK dimasukkan dalam bidang pembentukan perilaku merupakan kegiatan yang dilakukan secara terus menerus dan ada dalam kehidupan sehari-hari anak di TK, sehingga aspek-aspek perkembangan tersebut diharapkan berkembang secara optimal. Tujuan yang hendak dicapai dengan penanaman nilai-nilai/ pembentukan perilaku tersebut dilakukan melalui pembiasaan dalam rangka mempersiapkan anak sedini mungkin mengembangkan sikap dan perilaku yang didasari oleh nilai agama dan moral sehingga dapat hidup sesuai dengan norma-norma yang dianut oleh masyarakat. Salah satu diantaranya adalah membiasakan mengucapkan terimakasih ungkapan rasa syukur kepada diri Tuhan dan kepada oranglain yang telah memberikan kebahagiaan lahir dan bathin.

Berdasarkan hasil penelitian, maka Penanaman Nilai Moral Berupa Pembiasaan Anak Usia 4-5 Tahun Di Kecamatan Pontianak Kota Untuk Mengucapkan Terima Kasih, secara keseluruhan 69,52\%. Faktor-faktor yang mempengaruhi nilai moral dalam pelaksanaan pembiasaan pada anak untuk mengucapkan terima kasih dilakukan oleh orang tua adalah keluarga, sekolah, dan pengaruh teman sebaya/lingkungan. Upaya yang dilakukan orang tua untuk membiasakan anaknya mengucapkan terima kasih yakni dengan cara menjadi contoh teladan bagi anak seperti mengucapkan terima kasih kepada anak apabila anak telah melakukan perbuatan yang baik dan mau menolong orang tuanya begitu juga di sekolah, orangtua selalu mengingatkan anak untuk berterima kasih saat memperoleh sesuatu baik dari Tuhan maupun dari orang lain, membacakan cerita teladan tentang pembiasaan mengucapkan terima kasih.
\end{abstract}

\footnotetext{
${ }^{1}$ Halida adalah : dosen Prodi PAUD FKIP Untan

${ }^{2}$ Triwirawati adalah mahasiswa Prodi PAUD FKIP Untan
} 


\section{PENDAHULUAN}

Usia Dini merupakan masa keemasan (golden age) yang hanya terjadi satu kali dalam perkembangan kehidupan manusia (Papalia, 2008). Masa ini sekaligus merupakan masa yang kritis dalam perkembangan anak. Masa-masa tersebut merupakan masa kritis dimana seorang anak membutuhkan rangsangan-rangsangan yang tepat untuk mencapai kematangan yang sempurna. Jika pada masa ini anak kurang mendapat perhatian dalam hal pendidikan, perawatan, pengasuhan dan layanan kesehatan serta kebutuhan gizinya dikhawatirkan anak tidak dapat tumbuh dan berkembang secara optimal. Wiwin Dinar Pratisti ( 2008: 56)

Dalam Undang-Undang No. 20 Tahun 2003 tentang Sistem Pendidikan Nasional Bab 1, Pasal 1, Butir 14 dinyatakan bahwa "Pendidikan Anak Usia Dini adalah suatu upaya pembinaan yang ditujukan kepada anak sejak lahir sampai dengan usia 6 tahun yang dilakukan melalui pemberian rangsangan pendidikan untuk membantu pertumbuhan dan perkembangan jasmani dan rohani agar anak memiliki kesiapan dalam memasuki pendidikan lebih lanjut".

Salah satu sikap dasar yang harus dimiliki seorang anak untuk menjadi seorang manusia yang baik dan benar adalah memiliki sikap dan nilai moral yang baik dalam berperilaku sebagai umat Tuhan, anak, anggota keluarga dan anggota masyarakat.

Perkembangan awal usia 2-5 tahun merupakan masa keemasan (Golden Age). Perkembangan ini lebih kritis dari perkembangan selanjutnya (Hariwijaya dan Bertiani, 2009). Usia dini adalah saat yang paling baik bagi orang tua dan guru untuk meletakkan dasar-dasar pendidikan nilai, moral, dan agama kepada anak Taman Kanak-kanak.

Salah satu bagian penting yang harus mendapatkan perhatian terkait dengan pendidikan yang diberikan sejak usia dini adalah penanaman nilai moral melalui pendidikan di Taman Kanak-kanak. Pendidikan nilai dan moral yang dilakukan sejak usia dini, diharapkan pada tahap perkembangan selanjutnya anak akan mampu membedakan baik buruk, benar salah, sehingga ia dapat menerapkannya dalam kehidupan sehari-hari. Hal itu akan berpengaruh pada mudah tidaknya anak diterima oleh masyarakat sekitarnya dalam hal bersosialisasi.

Pendidikan nilai dan moral sejak usia dini merupakan tanggungjawab bersama semua pihak. Salah satu lembaga pendidikan yang dapat melakukan hal itu adalah Taman Kanak-kanak (TK) yang merupakan salah satu lembaga 
Pendidikan Anak Usia Dini (PAUD) yang bersifat formal. Di samping masih banyak lembaga PAUD lain yang dapat digunakan sebagai tempat penanaman nilai moral seperti: Kelompok Bermain (KB), Tempat Penitiapan Anak (TPA), pendidikan keluarga, dan pendidikan lingkungan.

Nilai dan moral merupakan dua kata yang seringkali digunakan secara bersamaan. Menurut Spranger dalam Asrori (2008: 129) mengatakan bahwa nilai adalah suatu tatanan yang dijadikan panduan oleh individu untuk menimbang dan memilih alternatif keputusan dalam situasi sosial tertentu. Dalam persepektif Spranger, kepribadian manusia itu terbentuk dan berakar pada tatanan nilai-nilai dan kesejarahan. Nilai mempunyai harga, hal-hal yang penting atau berguna bagi kemanusiaan. Menurut I Wayan Koyan (2000 :12), nilai adalah segala sesuatu yang berharga. Menurutnya ada dua nilai yaitu nilai ideal dan nilai aktual. Nilai ideal adalah nilai-nilai yang menjadi cita-cita setiap orang, sedangkan nilai aktual adalah nilai yang diekspresikan dalam kehidupan sehari-hari. Menurut Richard Merill dalam I Wayan Koyan (2000 : 13) nilai adalah patokan atau standar yang dapat membimbing seseorang atau kelompok ke arah "satisfication, fulfillment, and meaning".

Adapun pengertian moral menurut Asrori (2008:131) berasal dari bahasa latin mores, dari suku kata mos yang artinya adat istiadat, kelakuan, watak, tabiat, akhlak. Dalam perkembangannya moral diartikan sebagai kebiasaan dalam bertingkah laku yang baik, yang susila. Dari pengertian tersebut dinyatakan bahwa moral adalah berkenaan dengan kesusilaan. Seorang individu dapat dikatakan baik secara moral apabila bertingkah laku sesuai dengan kaidah-kaidah moral yang ada. Sebaliknya jika perilaku individu itu tidak sesuai dengan kaidah-kaidah yang ada, maka ia akan dikatakan jelek secara moral.

Anak-anak sangat memerlukan bantuan orang dewasa yang bertanggungjawab terhadap pengasuhan dan pendidikan anak dalam mempelajari nilai moral. Bruce dalam Winda Gunarti (2010) mengungkapkan bahwa membantu anak mengembangkan nilai moralnya dapat dilakukan apabila melakukan hal-hal sebagai berikut:

a) merawat anak dengan penuh kasih sayang;

b) memberikan banyak kesempatan pada anak untuk berdiskusi dan bernegosiasi;

c) menjelaskan suatu hal, maka anak perlu dibantu untuk mengekspresikan pikiran dan perasaannya tentang berbagai macam persoalan dan peristiwa yang dihadapinya;

d) mendukung anak untuk bergabung dengan penuh arti dengan anakanak lainnya; 
e) memberikan kesempatan kepada anak untuk bermain bebas karena akan mendorong anak melihat segala sesuatu dari sudut pandang oranglain; f) perlu memberikan penghargaan terhadap tingkah laku yang baik.

Marthin L. Hoffman (William M. Kurtines, 1992: 470) mengemukakan bahwa kepekaan seseorang mengenai kesejahteraan dan hak orang lain merupakan pokok persoalan ranah moral. Kepekaan tersebut mungkin tercermin dalam kepedulian seseorang akan konsekuensi tindakannya bagi orang lain, dan dalam orientasinya terhadap pemilikan bersama serta pengalokasian sumber pada umumnya. Ketika anak-anak berhadapan pada pertentangan seperti yang telah dikemukakan di atas, maka diharapkan teori developmental dapat mengatasinya. Dengan kata lain, teori ini memusatkan perhatian secara khusus pada bagaimana cara anak-anak menghadapi pertentangan tersebut. Selain itu, proses yang mereka lakukan dalam menyelesaikan permasalahan moral dapat untuk memotivasi agar memperhatikan kepentingan orang lain dan kecenderungan untuk merasa tidak senang manakala mereka tidak memperhatikan kepentingan orang lain. Proses pendidikan karakter yang berlangsung secara alami dalam lingkungan keluarga, memberikan ruangan yang luas bagi kedua orang tua untuk menerapkan cara-cara atau pendekatan yang lebih tepat. Faktor pertama yang harus dapat ditunjukkan oleh setiap orangtua adalah keteladanan. Orangtua harus menjadi inspirasi bagi anak-anak untuk menentukan cara memilih dan menentukan tindakan yang leibh baik, menjadi inspirasi pula'dalam etika, sopan santun dan akhlak sehari-hari. Karena perilaku kedua orangtua di dalam menyelesaikan masalah bagi anak-anak adalah suatu referensi yang ia simpan baik-baik di dalam benaknya. Anak-anak adalah saksi yang seslalu memperhatikan moralitas orang dewasa.(Aunurrahman, 2010)

Kehidupan sehari-hari anak di rumah dan lingkungan keluarga, tentunya berperan dalam pembentukan moral anak. Orang tua sebagai peran utama dalam perkembangan anak perlu memperhatikan kebiasaan anak mulai dari hal yang paling kecil seperti mengucapkan terimakasih atas sesuatu hal atau benda yang ia peroleh. Mengingat kata AA gym (dalam.www.dudung.net/artikel-islam/berburu-pahala-di-kantor.html), mulailah dari yang paling kecil dan dimulai dari sekarang. Maka pembiasaanpembiasaan perilaku yang baik dapat dilakukan orang tua terhadap anaknya sejak dini dan dimulai dari hal-hal yang yang sederhana dan mendasar.

Membiasakan diri untuk mengucapkan terima kasih merupakan salah satu pengaplikasian nilai sopan santun dan erat kaitannya dengan pendidikan. 
Berhasil tidaknya penanaman nilai moral pada masa kanak-kanak akan sangat menentukan baik buruknya perilaku moral seorang anak pada masa selanjutnya (Papalia, 2008). Tidak dapat dipungkiri bahwa kehidupan awal seseorang akan berpengaruh terhadap perkembangan selanjutnya. Namun sebagian orang tua melalaikan kepentingan pembinaan anak untuk berterima kasih, bahkan menganggap hal tersebut sebagai hal yang sepele yang dapat diabaikan begitu saja, maka para orang tua tersebut tidak menyadari bahwa ia sebenarnya telah menjerumuskan anaknya ke arah perilaku yang negatif dan tidak mau mensyukuri nikmat yang ia peroleh.

Berikut ini akan dipaparkan tentang tingkat pencapaian perkembangan kelompok usia $4-5$ tahun bidang pembiasaan.

\begin{tabular}{|c|c|}
\hline $\begin{array}{c}\text { Lingkup } \\
\text { Perkembangan }\end{array}$ & $\begin{array}{l}\text { Tingkat Pencapaian Perkembangan Usia } 4-<5 \\
\text { tahun }\end{array}$ \\
\hline \multirow{6}{*}{$\begin{array}{l}\text { Nilai-nilai } \\
\text { Agama dan Moral }\end{array}$} & 1. Mengenal Tuhan melalui agama yang dianutnya. \\
\hline & 2. Meniru gerakan beribadah. \\
\hline & $\begin{array}{l}\text { 3. Mengucapkan doa sebelum dan/atau sesudah } \\
\text { melakukan sesuatu. }\end{array}$ \\
\hline & Mengenal perilaku baik/sopan dan buruk. \\
\hline & 5. Membiasakan diri berperilaku baik. \\
\hline & 6. Mengucapkan salam dan membalas salam. \\
\hline
\end{tabular}

Sumber: Peraturan Pemerintah No 58 tahun 2009

\section{Masalah Penelitian}

Rumusan masalah dalam penelitian ini terdiri dari masalah umum dan sub-sub masalah. Masalah penelitian ini adalah " Bagaimanakah nilai dan moral anak dalam pembiasaan pengucapan terima kasih pada anak usia 4-5 tahun di Kecamatan Pontianak Kota"?

\section{Tujuan Penelitian}

Mengetahui nilai moral anak dalam pembiasaan pengucapan terima kasih kepada Tuhan dan kepada oranglain. Tujuan lain untuk mengetahui faktor-faktor yang mempengaruhi nilai moral kebiasaan anak dalam mengucapkan terimakasih dalam kehidupan sehari-hari serta upaya apa saja yang perlu dikembangkan oleh orangtua dalam pembiasaan mengucapkan terima kasih kepada anak usia dini umur 4-5 tahun di Kecamatan Pontianak Kota. 


\section{METODOLOGI PENELITIAN}

Penelitian ini menggunakan metode penelitian deskriptif yang memaparkan fenomena nyata yang terjadi di lokasi penelitian. Subjek dalam penelitian ini adalah: Orang tua murid, gurunya dan anak di TK sekecamatan Pontianak Kota. Teknik Pengumpulan data dalam penelitian ini menggunakan angket yang diberikan kepada orangtua murid dan menggunakan wawancara. Wawancara ini menggunakan wawancara terstruktur dan tidak terstruktur.

Data yang dianalisis pada penelitian ini adalah data pada angket yang di isi oleh responden yakni orang tua mengenai pembiasaan anak mengucapkan terima kasih. Metode analisis yang digunakan dalam penelitian ini adalah Analisis Deskriptif Persentase. Deskriptif persentase menurut peneliti ini diolah dengan cara frekuensi dibagi dengan jumlah responden dikali $100 \%$. Adapun rumusnya adalah sebagai berikut:

Keterangan :

$$
P=\frac{f}{N} \times 100 \%
$$

$\mathrm{P}$ : Persentase

f : Frekuensi

$\mathrm{N}:$ Jumlah responde

$100 \%$ : Bilangan tetap

\section{HASIL DAN PEMBAHASAN}

Berdasarkan hasil analisis angket tentang nilai moral berupa pembiasaan pengucapan terima kasih anak usia dini, umur 4-5 di TK Sekecamatan Pontianak kota yang terdiri dari penanaman nilai moral anak terbiasa mengucapkan terima kasih, faktor-faktor yang mempengaruhi nilai moral pembiasaan pengucapan terima kasih, upaya yang dilakukan orang tua untuk membiasakan anaknya menanamkan nilai moral dalam mengucapkan terima kasih dalam kehidupan sehari-hari.

Untuk menjawab semua aspek di atas, akan diuraikan di bawah ini.

1. Penanaman Nilai Moral Berupa Pembiasaan Mengucapkan Terima Kasih. 
Anak usia 4-5 tahun di kecamatan Pontianak Kota sudah terbiasa mengucapkan terima kasih ketika diberi sesuatu dengan persentase 69,52\%. Adapun presentase sub aspeknya akan dijabarkan sebagai berikut: 51,22\% anak mengucapkan terimakasih setelah menerima sesuatu. 60,98 \% anak mengucapkan terima kasih setelah pekerjaan dibantu oleh oranglain. 80,49\% anak mengucapkan terimakasih setelah mendapatkan hadiah dihari ulang tahunnya. 60,98\% anak mengucapkan terimakasih setelah mendapatkan pertolongan ketika ia terjatuh. 56,1 \% anak mengucapkan terima kasih setelah ibu merapikan pakaiannya. $100 \%$ ditegur ketika belum mengucapkan terimakasih ketika dibantu. 65,85 \% mengucapkan terima kasih kepada Tuhan atas kesehatan tubuhnya. 60,98 \% anak mengucapkan terima kasih saat orang tua mengizinkannya untuk bermain di luar rumah. $87,81 \%$ anak berterima kasih kepada Tuhan saat ia berulang tahun. 70,73\% anak mengucapkan terima kasih kepada orang tua yang telah merawat dan mengasuhnya hingga ia sembuh dari sakit.

Berikut ini adalah grafik persentase pembiasaan pengucapan terimakasih

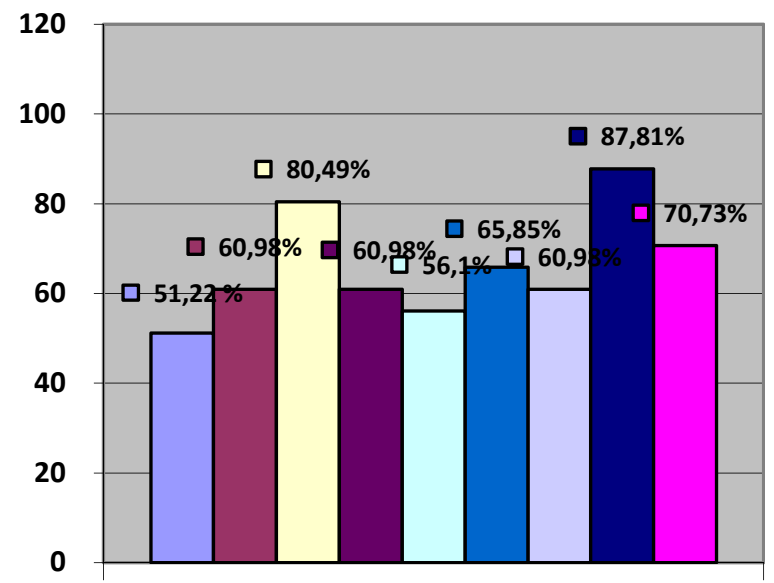

2. Faktor-faktor yang Mempengaruhi Nilai Moral Pembiasaan Pengucapan Terima kasih pada anak usia 4-5 tahun di Kecamatan Pontianak Kota

Faktor-faktor yang mempengaruhi nilai moral pembiasaan pada anak untuk mengucapkan terima kasih adalah keluarga, sekolah, dan teman 
sebaya anak. Dari ketiga faktor tersebut, faktor keluarga dan sekolah merupakan faktor yang paling utama.

Untuk melengkapi data, dilakukan wawancara dengan guru di sekolah. Jadi dari hasil wawancara dengan guru, dapat disimpulkan bahwa perilaku guru di sekolah memberi pengaruh penanaman pembiasaan pengucapan terimakasih pada anak. Guru bertugas memberikan contoh dan pengarahan serta mengingatkan anak untuk membiasakan diri untuk mengucapkan terima kasih, misalnya pada saat memperoleh makanan pada jam makan siang. Guru juga mengajarkan anak bersyukur kepada Tuhan saat anak memperoleh rezeki dan nikmat dari Allah. Sikap guru di sekolah menjadi model bagi siswa-siswanya.

Selain melakukan wawancara dengan guru di sekolah, peneliti juga melakukan wawancara dengan orang tua. Jadi dari hasil wawancara yang dilakukan dengan orangtua, dapat disimpulkan bahwa orangtua di rumah sangat berperan dalam pembentukan sikap dan pembiasaan anak untuk berterimakasih. Semua itu dilakukan dengan cara memberikan contoh teladan bagi anak dalam kehidupan sehari-hari. Dalam hal apapun yang didalamnya terkandung nilai, moral dan berkaitan dengan hal yang menyenangkan hati selalu dibiasakan dengan pengucapan terimakasih.

3. Upaya yang Dilakukan Orangtua untuk Menanamkan Nilai Moral dalam Pembiasaan Mengucapkan Terimakasih.

Keluarga merupakan faktor yang sangat mempengaruhi anak untuk terbiasa mengucapkan terima kasih. Orangtua menyadari akan pentingnya membiasakan anak mengucapkan terima kasih sejak dini. Orangtua yang membiasakan dan selalu mengingatkan anaknya untuk mengucapkan terima kasih setelah memperoleh sesuatu. Berbagai upaya yang dilakukan orang tua untuk membiasakan anaknya mengucapkan terima kasih seperti orangtua memberikan contoh teladan bagi anaknya untuk terbiasa mengucapkan terima kasih. Orang tua yang pernah membacakan cerita teladan untuk anaknya tentang pembiasaan terima kasih. Orangtua memberikan respon positif saat anaknya mengucapkan terima kasih kepadanya. Orang tua mengingatkan anaknya untuk terbiasa mengucapkan terima kasih.

\section{SIMPULAN}

Berdasarkan uraian hasil analisis, pelaksanaan pembiasaan pengucapan terima kasih pada anak usia 4-5 tahun di kecamatan Pontianak Kota dapat ditarik beberapa kesimpulan sebagai berikut. 
1. Penanaman Nilai Moral Berupa Pembiasaan Anak Usia 4-5 Tahun Di Kecamatan Pontianak Kota Untuk Mengucapkan Terima Kasih, secara keseluruhan 69,52\%.

2. Faktor-faktor yang mempengaruhi nilai moral dalam pelaksanaan pembiasaan pada anak untuk mengucapkan terima kasih yang dilakukan oleh orang tua kepada anaknya di kota Pontianak adalah keluarga, sekolah, dan teman sebaya. Di dalam keluarga, yakni pembiasaan sikap anak di rumah, pola asuh yang diterapkan orang tua, serta orang tua sebagai contoh teladan. Sedangkan di sekolah, yakni sikap guru dalam membiasakan anak mengucapkan terima kasih serta sikap guru sebagai contoh teladan bagi anak. Sedangkan teman sebaya anak mempengaruhi sikap anak saat anak bermain dan saling berinteraksi.

3. Upaya yang dilakukan orang tua untuk membiasakan anaknya mengucapkan terima kasih yakni dengan cara menjadi contoh teladan bagi anak, selalu mengingatkan anak untuk berterima kasih saat memperoleh sesuatu dari orang lain, membacakan cerita teladan tentang pembiasaan mengucapkan terima kasih. Orang tua dapat memberikan contoh bagi anaknya di rumah dengan cara mengucapkan terima kasih kepada anak apabila anak telah melakukan perbuatan yang baik dan mau menolong orang tuanya.

\section{DAFTAR PUSTAKA}

Asrori, M, 2008, Memahami dan Membantu Perkembangan Peserta Didik, Pontianak, Untan Press.

Aunurrahman. 2010. Membangun Kultur Keluarga Dan Sekolah Untuk Memperkokoh Pendidikan Karakter. Pontianak: Universitas Tanjungpura.

Gunarti, Winda, 2010, Metode Pengembangan Perilaku dan Kemampuan Dasar Anak Usia Dini, Jakarta, UT

Hariwijaya dan Bertiani. 2009. Melejitkan Potensi Anak dengan Pendidikan

Sejak Dini. Yogyakarta: Mahadika Publishing.

I Wayan Koyan. 2000. Pendidikan Moral Pendekatan Lintas Budaya. Jakarta: Depdiknas

Kirschenbaum, H. (1995). 100 Ways to Enhance Values and Morality in Schools and Youth Settings. Massachusetts: Allyn \& Bacon. 
Kurtines, William M. dan Gerwitz Jacob L. 1992. Moralitas, Perilaku Moral, dan Perkembangan Moral. Penerjemah: M.I. Soelaeman. Jakarta: UI-Press.

Otib Satibi Hidayat. 2000. Metode Pengembangan Moral dan Nilai-nilai Agama. Jakarta: Universitas Terbuka.

Papalia, E, Diane, 2008, Human Development, Psikologi Perkembangan. Jakarta, Kencana

Pratisti, Wiwien Dinar, 2008, Psikologi Anak Usia Dini, Jakarta, Indeks.

Sjarkawi. 2006. Pembentukan Kepribadian Anak. Jakarta: Bumi aksara.

Peraturan Pemerintah, Nomor 59 Tahun 2009.

http://tik2semdu.blogspot.com/2011/02/pendidikan-moral-dan-etika-sejakdini. html, Diunduh 28 April 2011

http://bbawor.blogspot.com/2008/08/penanaman-nilai-moral-untuk-anak sejak. html, Diunduh 18 Januari 2011

www.dudung.net/artikel-islami/berburu-pahala-di-kantor.html. Diunduh 28 April 2011. 